\title{
Edamame Production as Influenced by Seedling Emergence and Plant Population
}

\author{
Elsa Sánchez ${ }^{1}$, Kathleen Kelley ${ }^{2}$, and Lynn Butler ${ }^{3}$
}

ADDITIONAL INDEX WORDs. vegetable soybean, cultivars, plant populations, crop stand

SUMmaRY. Eight edamame (Glycine max) cultivars were evaluated in the field in 2002, 2003, and 2004 to determine suitability for growing in central Pennsylvania. Data collection included plant populations (percent stand), marketable and unmarketable yields and edamame pod and bean quality indicators. Plant populations varied by year and cultivar and were generally below $80 \%$. The effect of temperature on seedling emergence, and therefore plant populations, was evaluated for four edamame cultivars by using growth chambers programmed with varying day/night temperature regimes. Seedling emergence varied by cultivar and was generally below $80 \%$ with two exceptions. When grown in a $70 / 60$ ${ }^{\circ} \mathrm{F}$ day/night temperature regime, 'Butterbeans', and 'Early Hakucho' exceeded $80 \%$ seedling emergence. In the field trial, plant populations affected marketable yields. Pod and bean quality were dependent on cultivar. Results indicated that 'Butterbeans', 'Early Hakucho', 'Green Legend', 'Shironomai', 'Butterbaby', and 'Lucky Lion' appear promising for growing in Pennsylvania based on pod and bean quality. However, the issue of poor seedling emergence and plant populations presents a major constraint to commercial production and needs to be studied further.

$\mathrm{E}$ damame, also known as vegetable soybean, is specialty cultivars of soybeans that are harvested at an immature stage (R6 stage) and for direct consumption by humans (Rao et al., 2002). Edamame beans are bred to be large and sweet, compared to agronomic soybeans (Mentreddy et al., 2002; Miles et al., 2000) and their flavor has been described as "flower-like" and "beany" (Johnson, 1999) or "buttery" (Johnson, 2000). Edamame beans are versatile for their use in cooking and can be eaten alone or as a component of other dishes (Miles et al., 2000). Consumer reaction to a sensory evaluation of edamame beans was positive (Simonne et al., 2001). Consumers may benefit from eating edamame because it is nutritionally rich. Edamame beans contain $38 \%$ dry weight protein

Department of Horticulture, Pennsylvania State University, University Park, PA 16802 .

Use of trade names does not imply endorsement of the products named or criticism of similar ones not named. The authors would like to thank the USDA Federal State Marketing Improvement Program for funding this research.

${ }^{1}$ Assistant Professor of Horticultural Systems Management.

${ }^{2}$ Assistant Professor of Consumer Horticulture.

${ }^{3}$ Undergraduate Research Assistant.

\begin{tabular}{llll}
\hline $\begin{array}{l}\text { Units } \\
\text { To convert } \\
\text { U.S. to SI, } \\
\text { multiply by }\end{array}$ & U.S. unit & SI unit & $\begin{array}{l}\text { To convert } \\
\text { SI to U.S., } \\
\text { multiply by }\end{array}$ \\
\hline 0.4047 & acre $(\mathrm{s})$ & $\mathrm{ha}$ & 2.4711 \\
10.7639 & $\mathrm{fc}$ & $\mathrm{lx}$ & 0.0929 \\
29.5735 & $\mathrm{fl} \mathrm{oz}$ & $\mathrm{mL}$ & 0.0338 \\
0.3048 & $\mathrm{ft}$ & $\mathrm{m}$ & 3.2808 \\
3.7854 & $\mathrm{gal}$ & $\mathrm{L}$ & 0.2642 \\
2.5400 & inch $(\mathrm{es})$ & $\mathrm{cm}$ & 0.3937 \\
0.4536 & $\mathrm{lb}$ & $\mathrm{kg}$ & 2.2046 \\
1.1209 & $\mathrm{lb} / \mathrm{acre}$ & $\mathrm{kg} \cdot h \mathrm{~h}^{-1}$ & 0.8922 \\
28.3495 & $\mathrm{oz}$ & $\mathrm{g}$ & 0.0353 \\
28,350 & $\mathrm{oz}$ & $\mathrm{mg}$ & $3.5274 \times 10^{-5}$ \\
1 & $\mathrm{ppm}$ & $\mu \mathrm{gg} \cdot \mathrm{g}^{-1}$ & 1 \\
$\left({ }^{\circ} \mathrm{F}-32\right) 1.8$ & ${ }^{\circ} \mathrm{F}$ & ${ }^{\circ} \mathrm{C}$ & $\left(1.8 \times{ }^{\circ} \mathrm{C}\right)+32$
\end{tabular}

(Mentreddy et al., 2002; Miles et al., 2000 ) and $5 \%$ to $7 \%$ fresh weight lipids (Mentreddy et al., 2002). In general, soybeans are noted as one of the few sources of natural isoflavones (Mentreddy et al., 2002; Rao et al., 2002) and total isoflavone levels in edamame beans can range from 472 to 2280 $\mu \mathrm{g} \cdot \mathrm{g}^{-1}$, depending on cultivar and processing method (Simonne et al., 2000). Based on proximate compositional analysis in Colorado, a 100-g serving of edamame beans contains $72.0 \mathrm{mg}$ calcium, $148.0 \mathrm{mg}$ phosphorous, 1.2 $\mathrm{mg}$ iron, $1.5 \mathrm{mg}$ sodium, $145.0 \mathrm{mg}$ potassium, $89.0 \mathrm{mg}$ carotene, $0.27 \mathrm{mg}$ vitamin $B_{1}, 0.14 \mathrm{mg}$ vitamin $B_{2}, 1.0$ $\mathrm{mg}$ niacin, and $17.0 \mathrm{~g}$ ascorbic acid (Johnson, 1999). 
Growers may benefit from producing edamame because it can serve as a component of crop rotations and increase plant diversity, which can alleviate the risk of potential crop failure within the farming system (Mentreddy et al., 2002). Further, producing specialty crops, such as edamame, may offer growers an opportunity to develop profitable niche markets. Desired characteristics for marketing detached pods are bright green pods with light colored pubescence (Miles et al., 2000) containing two or more beans, large beans between 2.5 and $3.0 \mathrm{~g}$ fresh weight per pod, 33 to 42 pods in a 100-g sample (Gaskell, 2001; Nguyen, 1997), and white pubescence on the pods (Konovsky et al., 1994).

Edamame cultivar trials have been conducted in multiple locations in the U.S. to determine location and market suitability for production. The growth and development of individual edamame cultivars differed in response to local environmental factors, such as day-length and temperature (Gaskell, 2001; Miles et al., 2000). Optimum plant populations for edamame have not been previously proposed. However, for agronomic soybeans, germination below $80 \%$ is considered poor (Hatley and Yocum, 1983). Inferring from this value, $80 \%$ or above is considered as an optimum plant population for edamame. A commonality between many edamame field trials is the documentation of poor germination or deficient plant populations, based on $80 \%$ optimum plant populations, for many cultivars (Delate et al., 2001, 2002; Gaskell, 2001; Hemphill and Miles, 1998; Pearson, 2001; Rao et al., 2002). Poor germination and/or deficient plant populations have been attributed to improper planting depth (often too deep), soil crusting (Pearson, 2001) and seed size variability resulting in skips due to inability of seed to pass through seed plates (Miles, 1997). In this study, our objective was to evaluate eight edamame cultivars for horticultural characteristics and suitability for growing in central Pennsylvania. However, poor plant populations in the field led us to evaluate the edamame cultivars in the laboratory to determine if low seedling emergence and poor plant populations presents a major constraint to commercial production.

\section{Materials and methods}

Field TRIAL. Eight edamame cultivars (Table 1 ) were evaluated at the Horticulture Research Farm, Russell E. Larson Research Center, Rock Springs, $\mathrm{Pa}$. Cultivars were selected, and purchased each year, based on offerings from seed sources supplying the U.S. The field soil type was a Hagerstown silt loam. Nitrogen fertilizer was broadcast applied at a rate of $25 \mathrm{lb} /$ acre prior to planting and 6 weeks after planting (Miles et al., 2000). Soil tests (Mehlich 3 test) indicated optimal amounts of phosphorus and potassium in both trial years. Seeds were inoculated with Bradyrhizobium japonicum and hand planted to a depth of 0.5 inch on 22 May 2002, 17 June 2003, and 25 May 2004 . Field plots were planted on 2$\mathrm{ft}$-wide raised beds in two staggered rows with 6 -inch spacing within a row and between rows. Beds were spaced $5 \mathrm{ft}$ center to center for a seeding rate of about 17,500 seeds/acre. Field plots were watered immediately after planting in 2002 and 2004. In 2003 a timely rain event negated the need for supplemental irrigation immediately after planting. Additionally, in 2002 , field plots were hand-watered on 25 and 29 May supplying each seed with $8 \mathrm{fl} \mathrm{oz}$ of water and plants were sprinkler irrigated, supplying 1 inch of water, on 18 July, 9 Aug., and 13 Aug. In 2003 and 2004, supplemental irrigation was not used. Weeds were managed by hand cultivation. While insects were not deemed to be a problem in 2002, soybean aphids (Aphis glycines) affected all cultivars in 2003. The soybean aphids were managed by natural populations of lady bird beetles (Coccinella septempunctata) and lady bird beetle larva.

Plants were harvested 14 to 28 Aug. 2002 and 11 to 18 Sept. 2003 when the plants reached the R6 stage (the majority of pods were $80 \%$ to $90 \%$ filled and soluble solids, taken using a refractometer (model N-20e; Atago USA, Kirkland, Wash.), were between $8.5 \%$ and $12.0 \%$; Johnson, 1999). Plant populations, marketable and unmarketable yield, the number and weight of beans in 50 pods and the number of pods in $100 \mathrm{~g}$ were collected and recorded. Pods were considered marketable when they contained two or more beans and were unblemished. In 2004, plant population was the only variable evaluated because analysis of yield data from 2002 and 2003 harvests were thought to be of questionable value owing to poor plant populations.

GrowTH CHAMbER TRIAL. Four cultivars used in the field trial were evaluated in growth chambers in 2003 to study the effect of temperature on seedling emergence and therefore plant populations (Table 2). These cultivars were selected because they represented a wide range of plant populations based on the 2002 field trial. Three growth chambers (model M28; Environmental Growth Chambers, Chagrin Falls, Ohio) were used for the study and were programmed for a minimum relative humidity of $60 \%$ and 12 -h day lengths with $12,000 \mathrm{fc}$ of light during the day period. Additionally, the growth chambers were programmed on four day/night temperature regimes $(60 / 50,70 / 60,80 / 70$, and $90 / 80$ ${ }^{\circ} \mathrm{F}$ ) on 12 -h cycles. The $60 / 50{ }^{\circ} \mathrm{F}$ and $70 / 60{ }^{\circ} \mathrm{F}$ regimes corresponded approximately to soil temperatures used by Muendel (1986) to study the effects of seed moisture and soil temperature on emergence and vigor of agronomic soybeans. It has been documented that agronomic soybeans require a

Table 2. Plant populations of four edamame cultivars produced in growth chambers set at four day/night temperature regimes in 2003.

\begin{tabular}{|c|c|c|c|c|}
\hline \multirow[b]{2}{*}{ Cultivar } & \multicolumn{4}{|c|}{ Temperature regime $\left({ }^{\circ} \mathrm{F}\right)^{\mathrm{z}}$} \\
\hline & $60 / 50$ & $70 / 60$ & $80 / 70$ & $90 / 80$ \\
\hline & \multicolumn{4}{|c|}{-------- Plant population $(\% \text { stand })^{\mathrm{y}}$-------- } \\
\hline Butterbaby & $18 c^{x}$ & $21 \mathrm{~b}$ & $27 \mathrm{~b}$ & $5 \mathrm{~d}$ \\
\hline Shironomai & $38 \mathrm{bc}$ & $23 \mathrm{~b}$ & $28 \mathrm{~b}$ & $17 \mathrm{c}$ \\
\hline Early Hakucho & $78 \mathrm{a}$ & 89 a & $75 \mathrm{a}$ & $42 \mathrm{~b}$ \\
\hline Butterbeans & $57 \mathrm{~b}$ & $94 \mathrm{a}$ & $76 \mathrm{a}$ & $60 \mathrm{a}$ \\
\hline$P$ & $<0.01$ & $<0.01$ & $<0.01$ & $<0.01$ \\
\hline
\end{tabular}


Table 1. Plant populations of eight edamame cultivars produced in a field located at Rock Springs, Pa., in 2002, 2003, and 2004.

\begin{tabular}{|c|c|c|c|c|}
\hline \multirow[b]{2}{*}{ Cultivar } & \multirow[b]{2}{*}{ Seed source } & \multicolumn{3}{|c|}{ Plant population $(\% \text { stand })^{\mathrm{z}}$} \\
\hline & & 2002 & 2003 & 2004 \\
\hline Butterbaby & $\begin{array}{l}\text { W. Atlee Burpee Co., } \\
\text { Warminster, Pa. }\end{array}$ & $10 c^{y}$ & $<\mathrm{ld}$ & $47 \mathrm{~b}$ \\
\hline Shironomai & Stokes Seeds, Buffalo, N.Y. & $15 \mathrm{c}$ & $8 \mathrm{~cd}$ & $1 \mathrm{~cd}$ \\
\hline Green Legend & Evergreen Seeds, Anaheim, Calif. & $49 \mathrm{~b}$ & $9 \mathrm{~cd}$ & $14 \mathrm{c}$ \\
\hline Lucky Lion & Evergreen Seeds & $50 \mathrm{~b}$ & $6 \mathrm{~cd}$ & $<\mathrm{ld}$ \\
\hline Kenko & Seedex, Buffalo, N.Y. & $56 \mathrm{~b}$ & $<1 \mathrm{~d}$ & No data ${ }^{x-}$ \\
\hline Early Hakucho & Evergreen Seeds & $71 \mathrm{a}$ & $11 \mathrm{bc}$ & $3 \mathrm{~cd}$ \\
\hline Envy & $\begin{array}{l}\text { Johnny's Selected Seeds, } \\
\text { Albion, Maine }\end{array}$ & $72 \mathrm{a}$ & $19 \mathrm{~b}$ & $62 \mathrm{a}$ \\
\hline Butterbeans & Johnny’s Selected Seeds & $81 \mathrm{a}$ & $29 \mathrm{a}$ & $41 \mathrm{~b}$ \\
\hline$P$ & & $<0.01$ & $<0.01$ & $<0.01$ \\
\hline
\end{tabular}

${ }^{2} 100 \%$ plant population indicates that 40 seedlings emerged in the test plot.

Values are the mean sums of the seven replications. Values followed by different letters within years are significantly different using Fisher's least significant difference test at the $5 \%$ level.

'A seed source could not be identified for 'Kenko' in 2004.

minimum soil temperature of 46 to $50{ }^{\circ} \mathrm{F}$ for seed germination (Muendel, 1986). The $80 / 70$ and $90 / 80{ }^{\circ} \mathrm{F}$ regimes were selected to determine the effects of higher temperatures on edamame seedling emergence.

Seeds were inoculated with Bradyrhizobium japonicum and planted at a depth of 0.5 inch in soilless medium (Scotts Redi-Earth Plug Mix; Scotts Co., Marysville, Ohio) in 32-cell trays (Dillen T804; Dillen Products, Middlefield, Ohio) with flats (Dillen 1020). Immediately after planting, the medium was brought to field capacity by applying $3600 \mathrm{~mL}$ of water to each cell tray. Cell trays were then placed in the growth chambers programmed at the $60 / 50{ }^{\circ} \mathrm{F}$ day/night temperature regime. Seedling emergence, counted when cotyledons had emerged from the soil, was recorded daily for three weeks. These steps were repeated for the $70 / 60,80 / 70$ and $90 / 80^{\circ} \mathrm{F}$ temperature regimes. Seeds were watered with $0.95 \mathrm{gal}$ of water every $3 \mathrm{~d}$ in the $60 / 50{ }^{\circ} \mathrm{F}$ day/night temperature regime, every $2 \mathrm{~d}$ in the $70 / 60{ }^{\circ} \mathrm{F}$ day/night temperature regime and daily in the remaining temperature regimes. Watering regimes were based on visual (medium appeared dry) and tactile (medium was stiff to the touch) evaluation of medium moisture.

Statistical DESIGN AND ANALYsis. Cultivars in the field trials were arranged in a randomized complete block with seven replications. Treatment plots were $5 \times 20 \mathrm{ft}$ and contained 80 seeds/plot. Data were collected from the center $5 \times 10 \mathrm{ft}$ area of each plot. The interaction between year and level and therefore data were analyzed independently for each year. For the growth chamber trial, cultivars were arranged in a completely randomized design with three replications, represented by different growth chambers. Sixty-four seeds of each cultivar were planted for each replication. All data were analyzed using general linear model analysis of variance [GLM ANOVA (Number Cruncher Statistical System; NCSS Statistical Software, cultivar was significant at the $P \leq 0.05$

Kaysville, Utah). When significant differences at $P \leq 0.05$ were detected using GLM ANOVA, Fisher's least significance difference test was used to separate means.

\section{Results and discussion}

Using $80 \%$ or above as an optimum plant population for edamame, optimum plant populations were observed only for 'Butterbeans' in 2002 (Table 1). In 2003 and 2004, sub-optimal plant populations were observed for all cultivars. Other researchers have also observed plant populations below $80 \%$ (between $42 \%$ and $78 \%$ ) when producing edamame from directly sown seed (Delate et al., 2001, 2002; Hemphill and Miles, 1998).

Minimum and maximum air temperatures differed by 6.7 and $3.2^{\circ} \mathrm{F}$ during the germination and emergence period in 2002 and 2003, respectively (Fig. 1). To further investigate the influence of temperature on seedling emergence and therefore plant populations, the growth chamber trial was conducted. Air temperatures significantly impacted seedling emergence. Considering $80 \%$ or above as optimum seedling emergence, 'Butterbaby' and 'Shironomai' did not reach optimum seedling emergence at any of the temperature regimes used (Table 2 ).

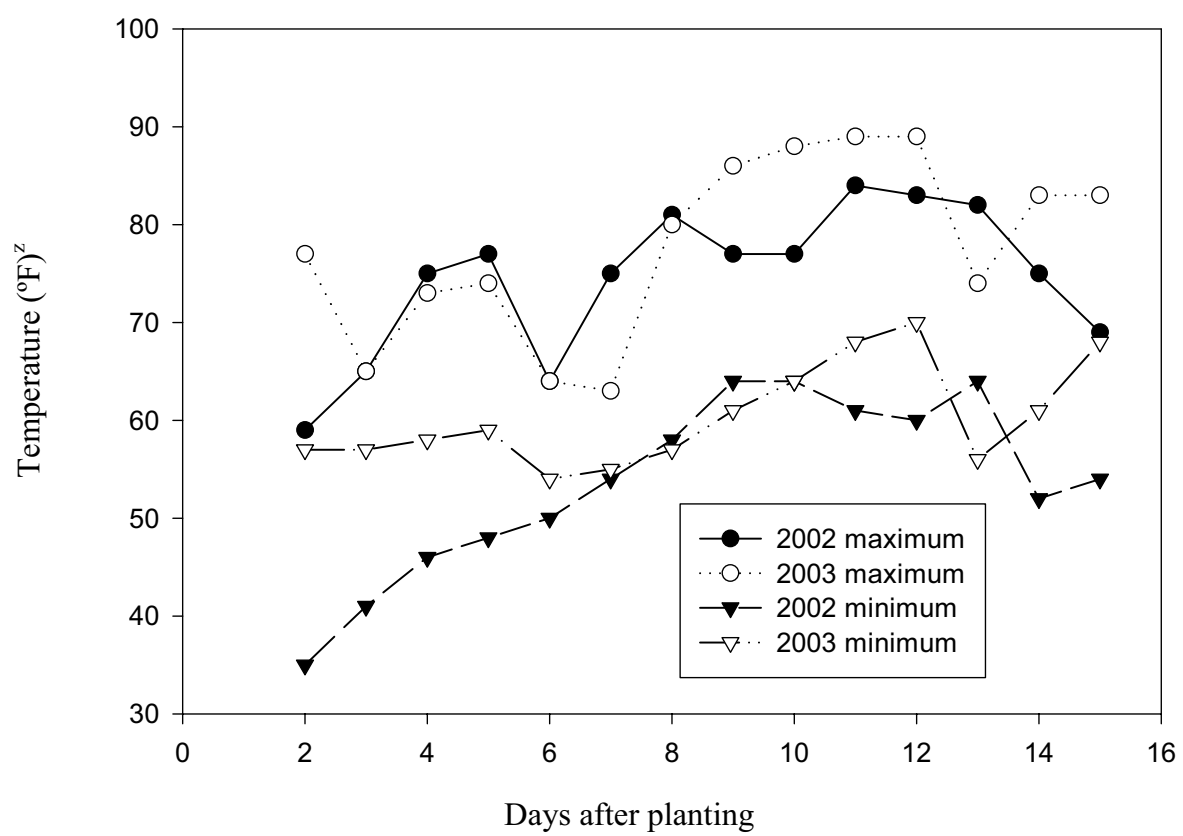

Fig. 1. Daily maximum and minimum air temperatures from the date of planting edamame seed to 2 weeks after planting. Seeds were planted on 22 May 2002 and 17 June 2003. The field was located at Rock Springs, Pa. Data were adapted from the U.S. Department of Commerce (2002a, 2002b, 2003); $\left({ }^{\circ} \mathrm{F}-32\right) \div 1.8$ $={ }^{\circ} \mathrm{C}$. 
Optimum seedling emergence was observed for 'Butterbeans' and 'Early Hakucho' at the $70 / 60^{\circ} \mathrm{F}$ day/night regime.

Planting too deep, skips due to variable seed size, and soil crusting have been implicated in poor seed germination and therefore reduced plant populations. In the field and growth chamber trials seed were planted at a depth of 0.5 inch, within the recommended planting depth of 0.25 to 0.5 inch for edamame (Miles et al., 2000). Skips due to the inability of seed to pass through seed plates were not a factor in the trials as all seed were planted by hand. Soil crusting likely influenced plant populations in 2003. In 2003, the site received $2.7 \mathrm{~cm}$ of rainfall the day after planting, which resulted in soil crusting. Soil surface crusting has been shown to reduce seedling emergence, notably of plants with epigeal cotyledon emergence like soybeans, by impeding oxygen diffusion to the seed and/or physically obstructing seedling emergence (Rathore et al., 1983). This can lead to sub-optimal plant populations (Rathore et al., 1983). In 2002 and 2004, however, the site received sufficient moisture through supplemental irrigation and rainfall during the germination period (7 to $14 \mathrm{~d}$ after planting) to preclude surface crusting. In the growth chamber trial the soilless medium was moist throughout the germination period and surface crusting was not observed. Other factors leading to sub-optimal plant populations need to be investigated including soil environment interactions with the seed (Miles and Chen, 2000), seed crop management and handling and genotype.
Yield data were collected from the 2002 and 2003 edamame crops. However, due to poor plant populations, yield data are inconsequential. Field studies have concluded that agronomic soybean plants can compensate, in terms of marketable yield, for plants missing in sub-optimal plant populations (Pepper and Walker, 1988; Roth et al., 2004; Stivers and Swearingin, 1980). Plant compensation and suboptimal plant populations render yield comparisons between cultivars questionable. Thus, yield data are referred to only to document that rough ranking of the cultivars in terms of marketable yield were similar.

Edamame pod and bean quality can be compared among cultivars (Table 3). In 2002, 'Shironomai' and 'Lucky Lion' had the lowest number of beans per pod and 'Early Hakucho' had the highest number of beans per pod. In 2003, the mean number of beans per pod was similar regardless of cultivar. During harvest, pods with two or more beans were selected as marketable and therefore all of the cultivars met the criterion of having a minimum of two beans per pod (Gaskell, 2001; Nguyen, 1997).

Mean bean weight per pod was lower than $2.5 \mathrm{~g}$ fresh weight, the minimum value recommended by Nguyen (1997) based on Australian and Asian markets, for all cultivars in both years. This can be partially attributed to the lack of supplemental irrigation throughout the growing season. In this study, we relied on natural rainfall to coincide with moisture management practices employed by the majority of Pennsylvania vegetable growers (U.S. Dept. of Agriculture, 2004). It has been recommended that edamame plantings receive 12 to 16 inches of water during the growing season (Miles et al., 2000). The study area receives almost 19 inches of rain during the growing season (National Climate Data Center, 2000) indicating that rainfall may be sufficient for supplying water. However, rainfall events are sporadic and may have influenced mean bean weight and pod size. Nonetheless, in a trial in Georgia, including 14 genotypes and using overhead sprinkler irrigation during the growing season, mean bean weights per pod were consistently lower than observed in the present study (Rao et al., 2002). In 2002, beans from 'Envy' pods were smaller than from all other cultivars except 'Lucky Lion.' Beans from 'Lucky Lion' pods were similar in size to all other cultivars. In 2003 , mean bean weights per pod were lower from 'Lucky Lion' and 'Envy' than from 'Green Legend', 'Early Hakucho', and 'Butterbeans'. Mean bean weight per pod from 'Shironomai' was similar to all other cultivars. Based on the number of pods in 100 $\mathrm{g}$, 'Shironomai' produced larger pods than all other cultivars in 2002. In 2003 , pods from 'Envy' were smaller than from all other cultivars. According to Gaskell (2001), the desired number of pods in $100 \mathrm{~g}$ is between 33 and 42. In this study, 'Shironomai' and 'Butterbaby' met this criterion in 2002 and 'Kenko', 'Green Legend', 'Early Hakucho', and 'Butterbeans' met this criterion in 2003.

In this study, our goal was to evaluate eight edamame cultivars for horticultural characteristics and suitability for growing in central Pennsylvania. 'Butterbeans', 'Early Hakucho',

Table 3. Bean and pod quality indicators for eight edamame cultivars produced in a field located in Rock Springs, Pa., in 2002 and 2003.

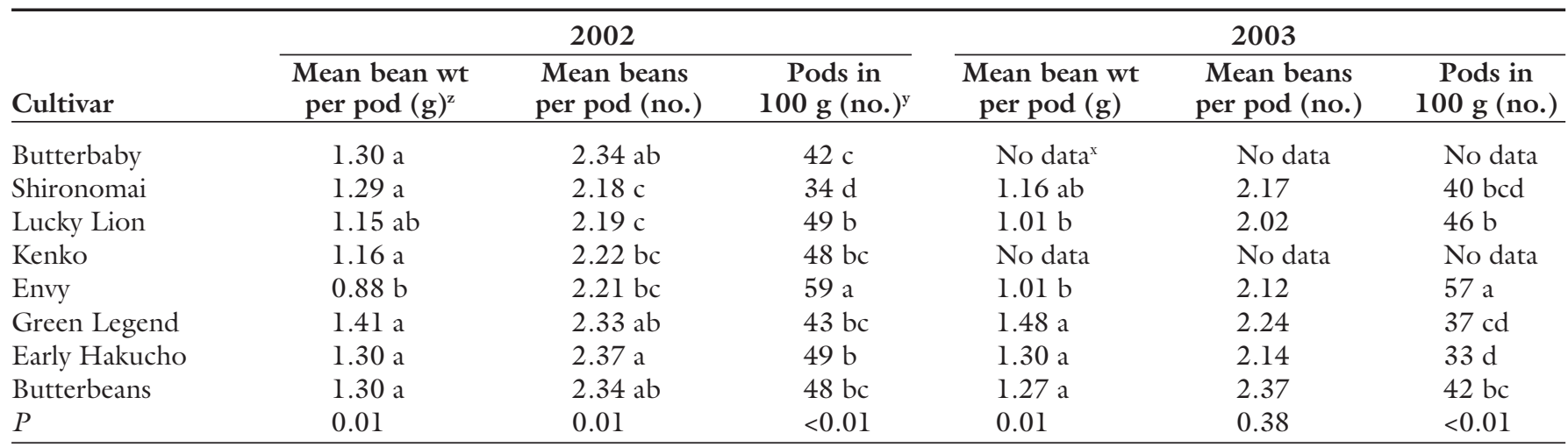

${ }^{2}$ Values followed by different letters within columns are significantly different using Fisher's least significant test at the $5 \%$ level; $1 \mathrm{~g}=0.0353 \mathrm{oz}$.

y 1 pod $/ 100 \mathrm{~g}=4.54$ pods $/ \mathrm{lb}$.

'In 2003 data were not collected from 'Butterbaby' and 'Kenko' because plant populations were $<1 \%$. 
'Green Legend', 'Shironomai', 'Butterbaby', and 'Lucky Lion' performed well in the field trial based on bean and pod quality characteristics. However, none of the edamame cultivars evaluated are suitable for direct seeding in central Pennsylvania or other areas with similar environments because of suboptimal plant populations. In growth chamber trials, 'Early Hakucho' and 'Butterbeans' exceeded 80\% seedling emergence when grown in a 70/60 ${ }^{\circ} \mathrm{F}$ day/night temperature regime. These cultivars, when grown in this temperature regime, could be used to produce transplants. Field planting transplants (Ernst, 2001) can maximize plant populations as can over-seeding followed by plant thinning where necessary (Manyvong, 1997). However, edamame seed is expensive (Miles, 1997; Pearson, 2001) costing up to $\$ 25.00$ per $0.5 \mathrm{lb}$ and these techniques should be evaluated prior to implementation in order to determine their economic feasibility.

We evaluated eight edamame cultivars from five seed sources over 3 years in the field and found none to be suitable for direct seeding in Pennsylvania because of sub-optimal plant populations. Additionally, four cultivars were produced in growth chambers to evaluate four temperature regimes on seedling emergence and in that trial two cultivars met optimal seedling emergence when grown in one temperature regime. The cultivars evaluated represented a large percentage of the cultivars of edamame seed commercially available and results from this study are likely to be applicable to other cultivars. Currently, limited commercially available cultivars with suitable seedling emergence and plant populations presents a major constraint to commercial edamame production.

\section{Literature cited}

Delate, K., B. Burcham, H. Friedrich, N. Wantate, and L. Wilson. 2001. Edamame (vegetable soybean) variety trial at NeelyKinyon Farm-2001. I1 May 2004. <http://www.organicaginfo.org/record. cfm?pk_doc_id=2921\&doc_num $=1>$.

Delate, K., H. Friedrich, B. Burcham, W. Fehr, and L. Wilson. 2002. Edamame (vegetable soybean) variety trial: IDALS Specialty Grant Program-2002. 11 May 2004. < http://www.organicaginfo.org/record. cfm?pk_doc_id=2914\&doc_num $=2>$.

Ernst, M. 2001. Marketing new crops.
University of Kentucky Coop. Ext. Serv. 11 May 2004. <http://www.uky.edu/Ag/ HortBiz/edamame_pubs.html>.

Gaskell, M. 2001. 2001 Field trials with "edamame" vegetable soybeans. Central Coast Agr. Highlights Nwsl., Oct. 2001. 11 May 2004. <http://www.sbceo.k12. ca.us/ uccesbl/page3.htm>.

Hemphill, D.D. and C.A. Miles. 1998. Cultivar, $\mathrm{N}$ rate and between-row spacing on yield of edamame. Vegetable research at North Willamette Research and Education Center. Oregon State Univ. Coop. Ext. 11 May 2004. <http://oregonstate.edu/dept/NWREC/bienn98. html\#edamame>.

Hatley, E. and J.O. Yocum. 1983. Agronomy facts 1: Soybean production in Pennsylvania. Pa. State Univ. Coop. Ext. Publ. 83-338.

Johnson, D. 1999. Market improving for edamame. Colorado State University Coop. Ext. Agron. News 19:1-4.

Johnson, D. 2000. Edamame. Resource 7:11-12.

Konovsky, J., T.A. Lumpkin, and D. McClary. 1994. Edamame: The vegetable soybean, p. 173-181. In: A.D. O'Rourke (ed.). Understanding the Japanese food and agrimarket: A multifaceted opportunity. Haworth Press, Binghamton, N.Y.

Manyvong, V. 1997. Vegetable soybean varietal trial. 20 Aug. 2004. <http://www. arc-avrdc.org/pdf_files/Nongnut(14N).pdf>.

Mentreddy, S.R., A.I. Mohamed, N. Joshee, and A.K. Yadav. 2002. Edamame: A nutritious vegetable crop, p. 432-438. In: J. Janick and A. Whipkey (eds.). Trends in new crops and new uses. ASHS Press, Alexandria, Va.

Miles, C.A. 1997. Washington State University edamame variety trial. 19 Aug. 2004. <http://agsyst.wsu.edu/EdVarietyReport1997.pdf>.

Miles, C.A. and C. Chen. 2000. Washington State University edamame trials 2000. 20 Aug. 2004. < http://agsyst.wsu. edu/EdamameReport2000.pdf>.

Miles, C.A., T.A. Lumpkin, and L. Zenz. 2000. Edamame. Washington State Univ. Coop. Ext. Publ. PNW0525.

Muendel, H.-H. 1986. Emergence and vigor of soybean in relation to initial seed moisture and soil temperature. Agron. J. 78:765-769.

National Climatic Data Center. 2000. Climatography of the United States No. 84, 1971-2000 Daily normals of temperature, precipitation, and heating and cooling degree days. 5 Apr. 2004. <http://www.ncdc.noaa.gov/servlets / DNRM? coopid $=368449>$.

Nguyen, V.Q. 1997. Edamame (vegetable green soybean), p. 196-203. In: K. Hyde (ed.). The new rural industries: A handbook for farmers and investors. Austral. Govt. Rural Ind. Res. and Dev. Corp. 11 May 2004. <http://www.rirdc.gov.au/pub/ handbook/contents.html>.

Pearson, C.H. 2001. Seed production of edamame soybean in western Colorado. WCRC 2001 annual report. 6 Jan 2003. $<$ www.colostate.edu/programs/wcrc/annrpt/01/Pearson_Edamame.html>.

Pepper, G.E. and J.T. Walker. 1988. Yield compensation for stand deficiencies by determinate and indeterminate growth-habit soybean. Agron. J. 80:1-4.

Rao, M.S., A.S. Bhagsari, and A.I. Mohamed. 2002. Fresh green seed yield and seed nutritional traits of vegetable soybean genotypes. Crop Sci. 42:1950-1958.

Rathore, T.R., B.P. Ghildyal, and R.S. Sachan. 1983. Effect of surface crusting on emergence of soybean (Glycine max L. Merr) seedlings I. Influence of aggregate size in the seedbed. Soil Tillage Res. 3:111-121.

Roth, G.W. 2004. Soybean, p. 68-72. In: E. Martz (ed.). The agronomy guide. Pa. State Univ. Coop. Ext. Publ. AGRS-26.

Simmone, A.H., M. Smith, D.B. Weaver, T. Vail, S. Barnes, and C.I. Wei. 2000. Retention and changes of soy isoflavones and carotenoids in immature soybean seeds (edamame) during processing. J. Agr. Food Chem. 48:6061-6069.

Simmone, A.H., D.B. Weaver, and C. Wei. 2001. Immature soybean seeds as a vegetable or snack food: Acceptability by American consumers. Innovative Food Sci. Emerging Technol. 1:289-296.

Stivers, R.K. and M.L. Sweringin. 1980. Soybean yield compensation with different populations of missing plants. Agron. J. 72:98-102.

U.S. Department of Commerce. 2002a. Pennsylvania May 2002. Climatol. Data 107(5):1-38.

U.S. Department of Commerce. 2002b. Pennsylvania June 2002. Climatol. Data 107(6):1-34.

U.S. Department of Commerce. 2003. Pennsylvania June 2003. Climatol. Data 108(6):1-34.

U.S. Department of Agriculture. 2004. 2002 Census of agriculture, Vol. 1, Chap. 1: Pennsylvania state level data, Tables 8 and 9. 3 Nov. 2004. <http://www.nass. usda.gov/census/census02/volumel/ $\mathrm{pa} /$ indexl.htm $>$. 